\title{
An Improved and Simplified Method of Detecting the Acetylator Phenotype
}

\author{
DAVID A. PRICE EVANS \\ From the Department of Medicine, University of Liverpool
}

A genetic polymorphism has been shown in man for the metabolism of isoniazid (Knight, Selin, and Harris, 1959; Evans, Manley, and McKusick, 1960; Sunahara et al., 1963a, b), and has been shown to control acetylation (Evans, 1962; Jenne, 1963; Evans and White, 1964; Peters, Miller, and Brown, 1965). The acetylation of sulphadimidine (sulfamethazine) has been found to be under the same genetic control as isoniazid (Evans, 1962; Evans and White, 1964; Peters, Gordon, and Brown, 1965).

This communication presents evidence that the acetylator phenotype can be simply determined using sulphadimidine as a test drug.

\section{Materials and Methods}

Experimental subjects and patients are detailed in Table I. Subjects who had (i) a history of asthma, hay fever, or eczema; (ii) major gastro-intestinal surgery; (iii) a history of adverse reaction to any drug; or (iv) any other serious organic disease were excluded from these experiments.

Sulphadimidine dosages were given as commercially available-scored tablets each containing $500 \mathrm{mg}$. of drug.

For the chemical analyses, ammonium sulfamate and N-1-napthyl-ethylene-diamine dihydrochloride were British Diug Houses, Reagent Grade, while other chemicals were British Drug Houses, Analytical Grade. Pure powder sulphadimidine was used to prepare standard solutions.

Procedure on Experimental Subjects and Patients. Fasting subjects swallowed their dose of sulphadimidine (Table I) as crushed tablets with a little water. Two hours after drug ingestion the subjects were allowed tea (or coffee) and toast. Thereafter normal meals were allowed. Urine was collected according to Table I, the volume measured, and a portion stored at $-20^{\circ} \mathrm{C}$. to await analysis. A sample of venous blood was taken as indicated in Table I, and the serum separated and stored at $-20^{\circ} \mathrm{C}$. to await analysis.

Series I subjects were all dosed under the supervision

Received June 13, 1969. of the same research worker and all specimens were analysed by the same technicians. Series II subjects were dosed in different places under the supervision of different persons; and the specimens were analysed variously by different technicians in different laboratories.

When the samples were thawed before analysis, care was taken to ensure that the sulphadimidine and acetylsulphadimidine were completely redissolved. For this purpose urine samples were placed after thawing in a boiling water bath for five minutes while thawed sera were placed in a $37^{\circ} \mathrm{C}$. incubator for 1 hour.

Estimation of Sulphadimidine Concentration in Urine and Serum. Free $(F)$ and total $(T)$ sulphadimidine concentrations were estimated by the BrattonMarshall procedure, as given by Varley (1954). Unknowns were processed in duplicate, and a range of standards at $2,4,6,8$, and $10 \mu \mathrm{g}$. sulphadimidine per ml., together with suitable blanks, were processed in duplicate simultaneously.

Calculations. The percentage of sulphadimidine acetylated is given by the formula:

$$
\frac{\mathrm{T}-\mathrm{F}}{\mathrm{T}} \%
$$

TABLE I

PROCEDURE ON EXPERIMENTAL SUBJECTS AND PATIENTS

\begin{tabular}{l|c|c}
\hline \multicolumn{1}{c|}{ Series } & I & II \\
\hline Subjects & $\begin{array}{c}\text { Hospital staff; } \\
\text { tuberculosis } \\
\text { patients }\end{array}$ & $\begin{array}{c}\text { Medical students; } \\
\text { hospital staf; } \\
\text { doctors attending } \\
\text { a 'Workshop in } \\
\text { Clinical Pharma- } \\
\text { cology' }\end{array}$ \\
\hline $\begin{array}{l}\text { Dose of sulphadimidine } \\
\text { in mg./kg. metabolical- } \\
\text { ly active mass( }=\text { weight } \\
\text { to the power of } 0 \cdot 7)\end{array}$ & 160 (see Table II) & 40 (see Table III) \\
\hline $\begin{array}{c}\text { Time for which urine } \\
\text { collected }\end{array}$ & $\begin{array}{c}\text { All 8 hours follow- } \\
\text { ing drug } \\
\text { ingestion }\end{array}$ & $\begin{array}{c}\text { For 1 hour only; } \\
5 \text { to 6 hours } \\
\text { after drug inges- } \\
\text { tion }\end{array}$ \\
\hline $\begin{array}{c}\text { Timing of blood sample } \\
\text { (hours after drug } \\
\text { ingestion) }\end{array}$ & 8 & 6 \\
\hline
\end{tabular}




\section{Results}

The results are presented in Fig. 1 and 2.

A satisfactory separation of rapid and slow acetylator phenotype was obtained with both dosages. The percentage of sulphadimidine acetylated in serum seems to be a better phenotypic discriminanant than is the same parameter in urine. A figure of $37.5 \%$ serum sulphadimidine acetylated has been taken as the arbitrary dividing line between the phenotypes in Series I.

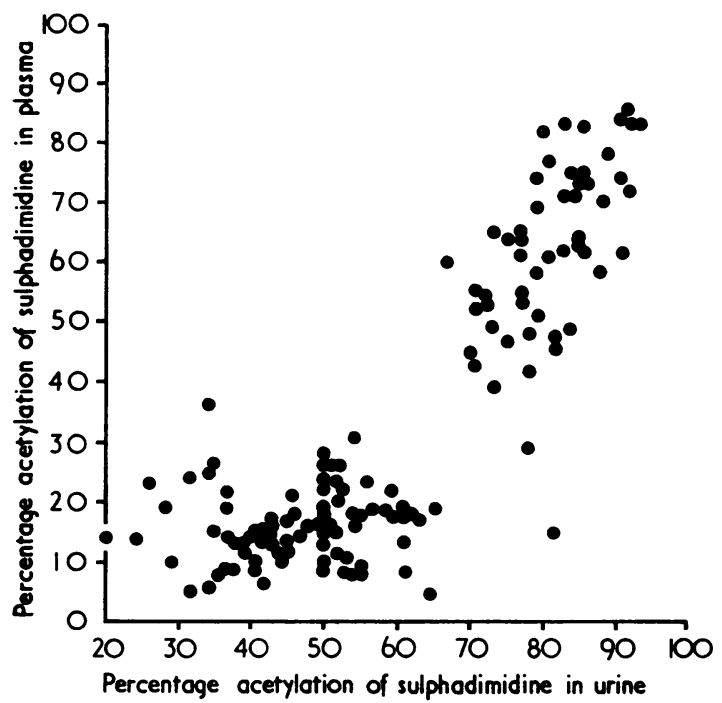

Fig. 1. Results on Series I.

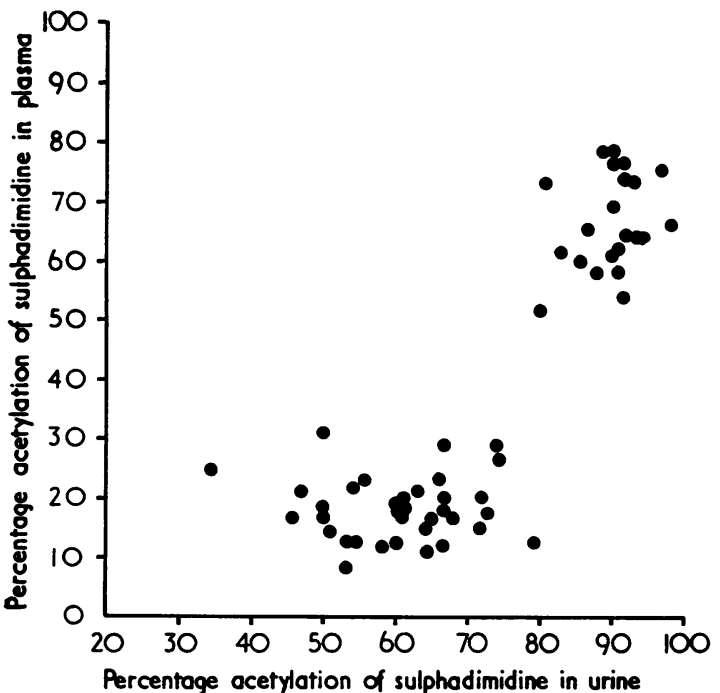

Fig. 2. Results on Series II.

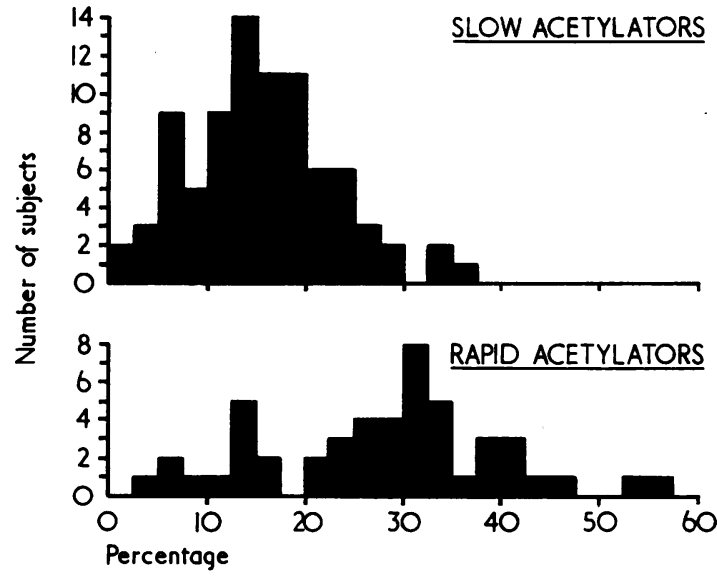

Fig. 3. Frequency distribution histograms of urinary elimination of ingested sulphadimidine in Series I subjects. The horizontal axis records the percentage of sulphadimidine dose excreted as total sulphadimidine in $\mathbf{8}$ hours after drug ingestion.

TABLE II

DOSAGE SCHEDULE $(160 \mathrm{mg}$ SULPHADIMIDINE/kg. METABOLICALLY ACTIVE MASS) FOR SERIES I (m.a.m. $=$ weight to the power of 0.7 ; Drabkin, 1959; Evans, Storey, and McKusick, 1961)

\begin{tabular}{c|c}
\hline $\begin{array}{c}\text { Body Weight } \\
\text { (kg.) }\end{array}$ & $\begin{array}{c}\text { Dose of } \\
\text { Sulphadimidine (mg.) }\end{array}$ \\
\hline $28 \cdot 1-34 \cdot 0$ & 1750 \\
$34 \cdot 5-40 \cdot 8$ & 2000 \\
$41 \cdot 3-47 \cdot 6$ & 2250 \\
$48 \cdot 0-54 \cdot 4$ & 2500 \\
$54 \cdot 9-61 \cdot 7$ & 2750 \\
$62 \cdot 1-69 \cdot 8$ & 300 \\
$70 \cdot 3-78 \cdot 0$ & 3250 \\
$78 \cdot 5-85 \cdot 7$ & 3500 \\
$86 \cdot 2-93 \cdot 9$ & 3750 \\
$94 \cdot 3-103 \cdot 0$ & 4000 \\
$103 \cdot 4$ and over & 4250 \\
\hline
\end{tabular}

TABLE III

SULPHADIMIDINE DOSAGE SCHEDULE FOR SERIES II (Approx. $11 \mathrm{mg} . / \mathrm{kg}$. body weight or $40 \mathrm{mg}$. $/ \mathrm{kg}$. metabolically active mass)

\begin{tabular}{c|c}
\hline $\begin{array}{c}\text { Body Weight } \\
\text { (kg.) }\end{array}$ & $\begin{array}{c}\text { Dose Sulphadimidine } \\
\text { (mg.) }\end{array}$ \\
\hline$<1$ to 83 & 500 \\
$>83$ & 750 \\
& 1000 \\
\hline
\end{tabular}


The incidence of serious headaches was 13 out of 41 in Series I ambulant patients and in hospital staff volunteer subjects following their normal duties. This incidence of adverse reactions was greatly reduced in Series I subjects who were made to lie down for at least 2 hours after drug ingestion. The incidence of such adverse reactions was very low in ambulant Series II subjects, e.g. only occurring in 1 in 16 subjects attending a 'Workshop in Clinical Pharmacology' (Royal Postgraduate Medical School).

These two population samples give an incidence of the slow acetylator phenotype of Series I $\frac{84}{135}=62 \cdot 2 \%$ and Series II $\frac{35}{57}=61 \cdot 4 \%$. All subjects in Series I were white British, but there were some non-British subjects in Series II.

The elimination of total (i.e. free plus acetylated) sulphadimidine in the 8 hours after drug ingestion, expressed as a percentage of the dose, can be compared between the two phenotypes in Series I subjects. For 49 rapid acetylators (urine volume was not recorded for 2 of the 51 shown in Fig. 1) the mean was $28.05 \pm$ SE 1.70; and for 84 slow acetylators the mean was $15.51 \pm$ SE 0.80 (Fig. 3). Both free sulphadimidine and acetylsulphadimidine concentrations are significantly inversely correlated with urine volumes. The percentage sulphadimidine acetylated is, however, not correlated with urine volume.

\section{Discussion}

A small series using the same technique as Series I was reported by White and Evans (1968), yielding a very similar result to those shown in Fig. 1 . Tiitinen (1969) has also published percentage free sulphadimidine in serum 5 hours after ingestion of a dose of $40 \mathrm{mg}$. sulphadimidine per $\mathrm{kg}$. body weight; the mean for 6 rapid acetylators was $55 \pm$ SE 7 and for 8 slow acetylators $85 \pm$ SE 3 . Her results are of a similar order to those obtained at 8 hours after drug ingestion in Series I of the present work and shown in Fig. 1. (Rapids 62.75 \pm SE 1.92\% serum sulphadimidine acetylated; slows $15 \cdot 74 \pm$ SE $0 \cdot 67 \%$ serum sulphadimidine acetylated.)

The technique of acetylator phenotyping employed in Series II gives very little side-effects in ambulant subjects, is simple to perform, and gives a good separation of phenotypes. The specimens are not harmed by being sent by mail to a suitable laboratory. For these reasons this method is suitable for field survey work, e.g. to assay gene frequencies, or to type patients who are to be treated in different locations in clinical experiments.

\section{Summary}

A method of determining the acetylator phenotype in man is described. This method uses a small dose of sulphadimidine which gives minimal side-effects. One serum and one urine specimen are required; they need no special handling and the laboratory analyses are simple. There is very little overlap between the two phenotypes by this method, and it is suggested that it is appropriate, e.g. for field work, to determine gene frequencies.

The author wishes to thank the following: The Mecical Research Committee of the United Liverpool Hospitals (Chairman, Professor C. A. Clarke) and the Nuffield Foundation (via, Professor C. A. Clarke) for generous financial support; the Matron and staff of Broadgreen Hospital, Liverpool, many of whom volunteered as subjects in Series I; Drs. J. Houston and C. A. Hopkins for help in testing patients at Aintree Hospital, many of whom volunteered as subjects in Series I; Professor C. Dollery and staff, Royal Postgradulate Medical School, London, who provided some volunteer subjects for Series II; Professor D. A. Mitchison, Royal Postgraduate Medical School, London, for helpful suggestions regarding the timing of specimens in Series II; and Miss M. F. Bullen, S.R.N. and Mr. Luke Eze for assistance in performing the phenotyping test in Series I.

\section{REFERENCES}

Drabkin, D. L. (1959). Imperfection: biochemical phobias and metabolic ambivalence. Perspect. Biol. Med., 2, 473.

Evans, D. A. P. (1962). Pharmacogenetique. Méd. et Hyg. (Genève), 20, 905.

- Manley, K. A., and McKusick, V. A. (1960). Genetic control of isoniazid metabolism in man. Brit. med. F., 2, 485.

- Storey, P. B., and McKusick, V. A. (1961). Further observations on the determination of the isoniazid inactivator phenotype. Bull. Fohns Hopk. Hosp., 108, 60.

, and White, T. A. (1964). Human acetylation polymorphism. F. Lab. clin. Med., 63, 394.

Jenne, J. W. (1963). Isoniazid acetylation by human liver and intestinal mucosa. Fed. Proc., 22, 540.

Knight, R. A., Selin, M. J., and Harris, H. W. (1959). Genetic factors influencing isoniazid blood levels in humans. In Trans. Conf. Chemotherapy of Tuberculosis (VA) 18th Conference, p. 52.

Peters, J. H., Gordon, G. R., and Brown, P. (1965). The relationship between the capacities of human subjects to acetylate isoniazid sulfanilamide and sulfamethazine. Life $S c i ., 4,99$.

$\longrightarrow$, Miller, K. S., and Brown, P. (1965). Studies on the metabolic basis for the genetically determined capacities for isoniazid inactivation in Man. f. Pharmacol. exp. Ther., 150, 298.

Sunahara, S., Urano, M., Lin, H. T., Cheg, T. J., and Jarumilinda, A. (1963a). Further observations on trimodality of frequency distribution curve of biologically active isoniazid blood levels and 'cline' in frequencies of alleles controlling isoniazid inactivation. Acta tuberc. scand., 43, 181.

- -,- , Ogwa, M., Yoshida S., Mukoyama, H., and Kawai, K. (1963b). Genetical aspect of isoniazid metabolism. fap. F. hum. Genet., 8, 93.

Tiitinen, H. (1969). Modification by para-aminosalicylic acid and sulfamethazine of the isoniazid inactivation in Man. Scand. $\mathcal{f}$. resp. Dis., 50 . In the press.

Varley, H. (1954). Practical Clinical Biochemistry. Heinemann, London.

White, T. A., and Evans, D. A. P. (1968). The acetylation of sulfamethazine and sulfamethoxypyridazine by human subjects. Clin. Pharmacol. Ther., 9, 80. 